\title{
Land-use influence on Mediterranean perennial swards of Poa bulbosa: a case study in the International Tagus Region
}

\author{
Sílvia Ribeiro (*), Paula Gonçalves (**) \& M. Dalila Espírito-Santo (*)
}

\begin{abstract}
Ribeiro, S., Gonçalves, P.\& Espírito-Santo, M.D. Land-use influence on Mediterranean perennial swards of Poa bulbosa: a case study in the International Tagus Region. Lazaroa 33: 51-64 (2012).

Pastureland abandonment or intensification of livestock activity change the floristic patterns of Mediterranean perennial swards which are very important to the conservation of some bird species. The objectives of this study are: 1) to recognise floristic patterns in Mediterranean perennial swards of Poa bulbosa; 2) to identify the communities that configure the European priority habitat $6220 *$ (Pseudo-steppe with grasses and annuals of the Thero-Brachypodietea); 3 ) to assess the effects of land-use management on the floristic composition of these communities. Field research was conducted in central eastern and south eastern main land Portugal.Vegetation sampling was carried out in 2009-2010 on 9 sward sites, following the phytosociological concepts. Classification and ordination of relevés were obtained by Two Way Indicator Species Analysis (TWINSPAN), Canonical Correspondence Analysis (CCA) and Detrended Canonical Correspondence Analysis (DCCA). Monte Carlo Permutation Tests were performed to analyse differences in floristic patterns. Livestock load, stoniness and land-use history of the last 10 years were selected as the key variables that best explain the ordination model. The absence of extensive livestock grazing results in a reduction of Trifolium subterraneum-dominated areas and in a density/cover reduction of Poa bulbosa-dominated areas. High livestock loads change the floristic patterns of Mediterranean short swards by favouring species of the Stellarietea mediae class. The control of woody vegetation through grazing or cutting is a key conservation measure.
\end{abstract}

Keywords: conservation, floristic patterns, management, Mediterranean short swards, priority habitat.

Resumen: Ribeiro, S., Gonçalves, P. \& Espírito-Santo, M.D. Influencia del manejo en los pastizales de Poa bulbosa: estudio en la región internacional del Tajo. Lazaroa 33: 51-64 (2012).

El abandono de los pastizales o la intensificación de la actividad ganadera cambia los patrones florísticos de pastizales mediterráneos perennes que son muy importantes para la conservación de algunas especies de aves. Los objetivos de este estudio son: 1) reconocer los patrones florísticos mediterráneos en pastizales de Poa bulbosa; 2) identificar las comunidades que configuran el hábitat prioritario Europeo 6220* (Zonas subestépicas de gramíneas y anuales de Thero-Brachypodietea); 3) evaluar los efectos de la gestión del uso del suelo en la composición florística de estas comunidades. El trabajo de campo se llevó a cabo en el centro-este y sudeste de la zona continental de Portugal. Los inventarios de dicha vegetación se realizaron en 2009-2010 en nueve localidades, siguiendo los conceptos fitosociológicos. La clasificación y ordenación de los inventarios se ha realizado por medio de análisis multivariables (TWINSPAN, CCA y DCCA). Además se realizó un test de permutación de Monte Carlo para analizar las diferencias en los patrones florísticos. La carga ganadera, la pedregosidad y la historia de uso del territorio de los últimos 10 años fueron seleccionadas por dicho test, como las variables que mejor explican el modelo de ordenación. La reducción del pastoreo extensivo disminuye las áreas dominadas por Trifolium subterraneum y la densidad/cobertura de aquellas áreas dominadas por Poa bulbosa. Las altas cargas ganaderas, por el contrario, cambian los patrones florísticos favoreciendo a las especies de la clase Stellarietea mediae. El control de la vegetación leñosa a través del pastoreo o corte es una medida clave para su conservación.

Palabras clave: Conservación, Patrones florísticos, Gestión, Praderas perennes mediterráneas, Hábitat prioritario.

* Centro de Botânica Aplicada à Agricultura. Instituto Superior de Agronomía. Tapada da Ajuda. 1349-017 Lisboa, Portugal. E-mail: silvia.sbenedita@gmail.com; dalialesanto@isa.utl.pt

** Parque Natural do Tejo Internacional/Instituto da Conservação da Naturaleza e da Biodiversidades. I.P., Rua da Bela Vista. 6000-458 Castelo Branco, Portugal; e-mail: pnti-goncalvesp@icnb.pt 


\section{INTRODUCTION}

Mediterranean natural and semi-natural grasslands are amongst the protected habitats in Europe, contributing to the so-called cultural landscapes (SAN Miguel, 2008). Pseudo-steppe with grasses and annuals of the Thero-Brachypodietea (Natura 2000 code: 6220*; EC, 2007) are a priority habitat under the European Union Habitats Directive (Council Directive 92/43/EEC on the conservation of natural habitats and of wild fauna and flora).

Due to its dependence on Mediterranean climate, the 6220 habitat occurs mainly in the Mediterranean region. In Portugal five subtypes were considered within this habitat type (ICNB, 2006). The Mediterranean perennial swards of Poa bulbosa (Class Poetea bulbosae) are included in subtype 2 (ICNB, 2006).

Studies on Mediterranean perennial short swards of the Trifolio subterranei-Periballion alliance in the Iberian Peninsula, at both the descriptive and/or management level, were mainly developed by RIVAS GODAY \& RIVAS MARTÍNEZ (1963), Rivas GODAY (1964), RIVAS GODAY \& LADERO (1970), AMOR \& al. (1993), LADERO \& al. (1994) and more recently by GALÁN \& al.(2000), and CANO \& al. (2007). These communities were also studied by SANTOS \& al.(1988), DE LA FUENTE (1985), IzCO \& al. (2000), ROMERO \& al. (1994), LOIDI ARREGUI \& al. (1997), MONSERRAT \& FILLAP (1999), Aguiar (2000), CANTó (2004), SÁNCHEZ RodRíGUEZ \& al. (2006) and SILVA \& al. (2009) in more restricted areas.

This study focuses on the Trifolio subterraneiPeriballion alliance which is often linked to the dehesa system. This alliance occurs throughout the silicicolous thermo- to supramediterranean dry to lower subhumid territories. These Mediterranean perennial swards dry up in early summer, but grow back fast after the first autumn rains and remain green and fertile during winter (RIVASMARTínEZ, 2007). They are found on both oligotrophic and eutrophic soils (SAN Miguel, 2008) which results in a floristic composition intruded by a large number of therophytes of the Tuberarietea guttatae class (oligotrophic soils) or of the Stellarietea mediae class (eutrophic soils). They are also especially linked to the transhumance migration routes, mainly for sheep, that lead to the mountainsummer pastures or those that connect the altitudinal areas to the autumn-winterspring pastures of the lower plains (GALÁN \& al., 2000).

The Mediterranean perennial swards of Poa bulbosa usually occur in a mosaic pattern with a wide variety of other plant communities. They are very positively selected by the European rabbit (Oryctolagus cuniculus; SAN Miguel, 2008) that has been identified as a keystone species to the Iberian ecosystem (IUCN, 2011a), as prey for specialist predators (VIRGOS \& al., 2005), as a landscape modeller (Delibes \& al., 2000; WARD, 2005) and as an agent for increasing soil fertility (WiLlotT \& al., 2000).

The International Tagus Region - border section of the Tagus River between Portugal and Spain, confining tributary valleys and adjacent plateaux - is well known for its importance in avian conservation. Part of this territory has been classified as a Portuguese natural park and as a Special Protection Area under the European Union Birds Directive (DIRECTIVE 2009/147/EC on the conservation of wild birds).

Endangered species such as the Iberian imperial eagle (Aquila adalberti; Conservation Status in Portugal: Critically Endangered (CABRAL \& al., 2005), Bonelli's eagle (Hieraaetus fasciatus; Conservation Status in Portugal: Endangered (CABRAL \& al., 2005), the black vulture (Aegypius monachus; Conservation Status in Portugal: Critically Endangered (CABRAL \& al., 2005), the golden eagle (Aquila chrysaetos; Conservation Status in Portugal: Endangered (CABRAL \& al., 2005) and the Egyptian vulture (Neophron pernocpterus; Conservation Status in Portugal: Endangered (CABRAL \& al., 2005) occur in the study area (ICNB, 2007) and depend, to a higher or lesser degree on wild rabbit and, consequently, on Poetalia bulbosae swards.

This study aims to invesgate the land-use influence on the floristic composition of Mediterranean perennial swards of investigate Poa bulbosa in the International Tagus Region. 


\section{MATERIAL AND METHODS}

\section{STUDY AREA}

Although fieldwork covered a total area of approximately $28700 \mathrm{~km}^{2}$ in central eastern and south eastern main land Portugal, only in the International Tagus Natural Park and neighbouring area were requirements met to assess the effects of land-use management on Mediterranean short swards of Poetea bulbosae. Sampling of these communities was carried out in the International Tagus Natural Park and adjacent areas (Figure 1) on siliceous rock (mainly schist). According to the biogeographic typology of RIVAS MARTínEZ (2007) the sampled area is included in the Western Mediterranean Subregion, Mediterranean West Iberian Province (Lusitan-Extremadurean Subprovince).

The altitudes of the surveyed sites range from 135 to $310 \mathrm{~m}$ above sea level. These sites fall within the upper thermomediterranean to lower mesomediterranean thermotype and upper dry to lower subhumid ombrotype climatic belts (RIVAS-MARTínez, 2005; MONTEIROHENRIQUes, 2010).

The communities under study occur in patches throughout extensive scrublands and dehesas which were intensively farmed with cereals in 1930-1940 (ChAmBino, 2000). Today forestry prevails in the study area, along with extensive sheep, goat, cattle and, to a lesser degree, pig grazing; olive growing and polyculture is concentrated around villages and sport hunting (especially big game sport hunting) is widespread (CARVALHINO, 2004).

The sampled communities are related to the corkoak Sanguisorbo agrimonioidis-Querco suberis $S$. and the holmoak Pyro bourgaeanae-Querco rotundifoliae $S$. climatophilous series.

Botanical nomenclature follows CASTROVIEJO \& al. (1986-2010), FRANCO (1971, 1984), Franco \& Rocha Afonso $(1994,1998)$ and PIZARRO (1995). Bioclimatological, Biogeographical and Syntaxonomical typology was checked according to RIVAS-MARTínEZ (2007).

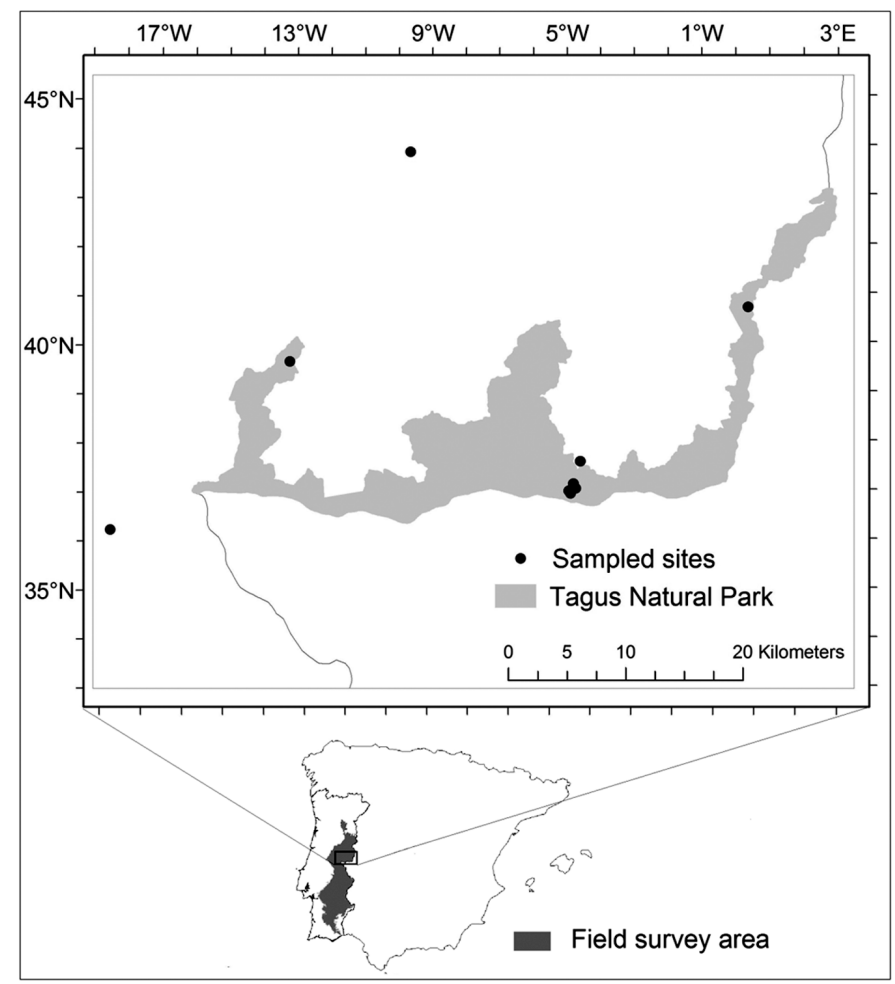

Figure 1. - Study area and location of the sampled Mediterranean short sward sites. 


\section{SAMPLING DESIGN AND DATA COLLECTION}

Field sampling was carried out on 9 Mediterranean short sward sites (26 relevés), following the phytosociological concepts of BRAUN-BALANQUET $(1964,1979)$ modified by GÉHU \& RIVAS-MARTíNEZ (1981). The communities were surveyed using the minimum area method (the smallest area which adequately represents community composition) in line with MUELLER-DOMBOIS \& ELLENBERG (1974). As suggested by CHYTRÝ \& OTÝPKOVÁ (2003), OTÝPKOVÁ \& CHYTRÝ (2006) and DENGLER \& al. (2009), the representative plot size of a homogenous floristic composition was set at $4 \mathrm{~m}^{2}$ in order to reduce the potential effects of different plot sizes in classification and ordination analyses. Each taxon's percentage cover was recorded to allow for multivariate analysis (PODANI, 2006). The percent cover of bryophytes was also registered for each relevé.

Predictor variables were recorded for each herb community, including both qualitative and quantitative environmental and land-use variables. These predictor variables were assigned to two groups: (i) environmental, (ii) land-use.

The environmental factors include: latitude, longitude, altitude, aspect, slope, rock type, percentage of stone (stoniness), soil texture, soil humidity and soil depth.

Land-use influence was evaluated by using: a) livestock load and b) regularity of grazing or livestock permanence. Four classes were considered for livestock load: 1 - Very light (very lightly grazed); 2- Light (extensive grazing); 3 - High (all year round permanence zones and high animal load with high animal density) and; 4 - Very high (penned and overloaded livestock areas). Four classes were defined for regularity of grazing or livestock permanence: 1 - Very irregular use during 6 months; 2 - Irregular use during 6 months; 3 - Regular use during 6 months and 4 - Regular uses all year round.

\section{DATA ANALYSIS}

The data set includes 26 relevés and 159 species. A hierarchical polythetic divisive classification was performed on the species data with
Twinspan for Windows version 2.3 (WinTWINS) (Hill \& Smilauer, 2005). Rare species were not excluded from the analysis and all species maintained default user weight (1.0). Nine pseudospecies cut levels were specified: $0(0-9 \%), 10$ $(10-19 \%), 20$ (20-29\%), 30 (30-39\%), 40 (40$49 \%), 50$ (50-59\%), 60 (60-69\%), 70 (70-79\%), $80(80-100 \%)$.

The major groups defined through Twinspan were tested with Monte Carlo Permutation Test (9999 permutations) in order to test the statistical significance of these groups.

According to JONGMAN \& al. (1995) a unimodal response can be detected by a Detrended Correspondence Analysis (DCA) if the gradient lengths exceed 2 SD. As this occurred in this study, the relationships between a species' occurrence and the main explanatory variables were assessed through Detrended Canonical Correspondence Analysis (DCCA) to avoid the arch effect. All data were log-transformed $\log (x+1)$ to improve normality. In order to detect collinearity between the explanatory variables, a forward selection (BORCARD \& al., 1992; HEIKKINEN \& al., 2004) was performed by the Monte Carlo Permutation Test (9999 permutations) in a previous CCA analysis which resulted in the exclusion of variables that did not contribute significantly $(p<0.05)$ to the ordination pattern. The variance inflation factors for the explanatory variables were examinated to detect collinearity.

All of the above analyses were performed with the CANOCO 4.5 software (TER BRAAK \& ŠMILAUER, 2002). The software JUICE 7.0.56 (TichÝ, 2002) was used to edit, analyse and produce the phytosociological tables.

\section{RESULTS}

\section{ClassificATION OF RELEVÉS}

The Twinspan classification (Figure 2) resulted in the definition of 14 groups. Since WinTWINS sets the minimum group size for division at 3, Divisions VII and $\mathrm{X}$ were determined by the authors. Division I $(\lambda=0.484)$ separates areas used 


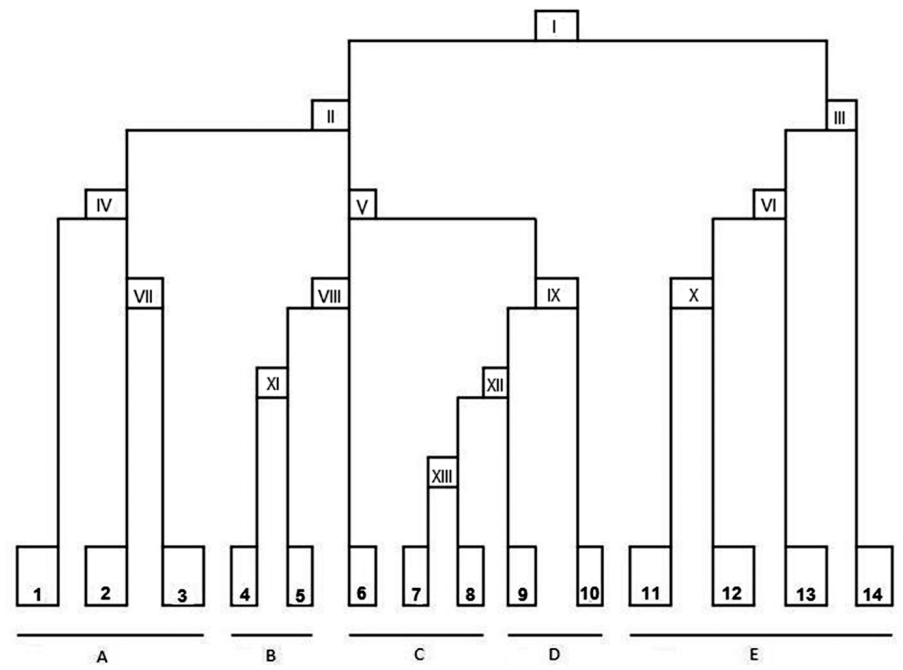

Figure 2. - Twinspan classification dendrogram.

continuously all year round - feeding and/or livestock areas - from those used regularly or irregularly during 6 months of the year. Poa bulbosa, Herniaria scabrida and Logfia gallica are exclusive negative preferentials occurring in two thirds of the sampled plots. Division II $(\lambda=0.391)$ divides penned livestock areas from communities with a cover-abundance of Poa bulbosa of $20 \%$ or more. Erodium moschatum, Amaranthus sp. and Sisymbrium officinale are faithful to the first group. Division III $(\lambda=0.667)$ isolates the Hordeum leporinum-dominated Group 14. Division IV $(\lambda=0.559)$ defines Group 1 - a Stellariete mediae community with Polygono-Poetea annuae species. Division V $(\lambda=0.347)$ clusters nine of the ten relevés with Erodium botrys in the 'negative group' and most of the relevés with Hypochaeris glabra, Tolpis barbata and Trifolium glomeratum in the 'positive' group. Division VI $(\lambda=0.607)$ results in the definition of Group 13 (corresponding to a fragmented Pulicario-Agrostietum salmanticae association with Stellarietea mediae companion species). Division VII separates a Stellarietea mediae community dominated by Geranium molle and Capsella bursa-pastoris with some species of the Hordeion leporini alliance (Group 2) from Stellarietea mediae community dominated by Capsella bursa-pastoris (Group 3). Division VIII $(\lambda=0.369)$ separates the abandoned Mediterranean short sward communi- ties (Poo bulbosae-Trifolietum subterranei) from the lightly grazed Mediterranean short sward community (Group 6). Division IX $(\lambda=0.440)$ sets Group 10 apart - edge community of extensively grazed Mediterranean short swards rich in Helianthemetea guttatae-Stellarietea mediae species and with Poa bulbosa. Division X results in two Groups: 11 (Stellarietea mediae community); and 12 (Echium plantagineum community). Division XI $(\lambda=0.580)$ distinguishes the Poo bulbosae-Trifolietum subterranei association according to the dominant species: Trifolium subterraneum in Group 4 and Poa bulbosa in Group 5. Division XII $(\lambda=0.474)$ delimits Group 9, an edge community of abandoned Mediterranean short swards rich in Helianthemetea guttatae-Stellarietea mediae species and with Poa bulbosa. Division XIII $(\lambda=0.457)$ divides the lightly grazed Trifolium subterraneum-dominated Mediterranean short swards (Group 7) from the lightly grazed Poa bulbosa-dominated ones (Group 8). Twinspan divisions, indicator species and defined groups with respective syntaxa are presented in Table 1.

The 14 groups were clustered into five sets (Sets A to E) that reflect their land-use history over the last decade: Set A- Penned livestock areas of Mediterranean short swards for at least 5 years (PLAMS); Set B - Abandoned Mediterranean short swards (rarely grazed by livestock) for 
Table 1

Twinspan divisions, indicator species and defined groups with respective syntaxa

\begin{tabular}{|c|c|c|c|c|}
\hline Division & $\begin{array}{l}\text { 'Negative' Group } \\
\text { Indicator(s) }\end{array}$ & $\begin{array}{l}\text { 'Positive' Group } \\
\text { Indicator(s) }\end{array}$ & Group & Syntaxa \\
\hline I & Poa bulbosa (1) & Bromus & - & - \\
\hline II & $\begin{array}{l}\text { Erodium } \\
\text { moschatum }(1)\end{array}$ & hordeaceus (1) & - & - \\
\hline III & Agrostis pourretii (1) & & 14 & Hordeum leporinum community \\
\hline IV & $\begin{array}{l}\text { Anarrhinum } \\
\text { bellidifolium (1) }\end{array}$ & & 1 & $\begin{array}{l}\text { Stellarietea mediae community with } \\
\text { Polygono-Poetea annuae species }\end{array}$ \\
\hline $\mathrm{V}$ & & $\begin{array}{l}\text { Hypochaeris glabra }(1) \\
\text { Spergularia purpurea }(1) \\
\text { Trifolium glomeratum }(1) \\
\text { Tolpis barbata }(1)\end{array}$ & - & - \\
\hline VI & $\begin{array}{l}\text { Capsella bursa- } \\
\text { pastoris (1) }\end{array}$ & & 13 & $\begin{array}{l}\text { Fragmented Pulicario-Agrostietum } \\
\text { salmanticaei association with Stellarietea } \\
\text { mediae companion species }\end{array}$ \\
\hline VII & & & 2 & $\begin{array}{l}\text { Stellarietea mediae community dominated } \\
\text { by Geranium molle and Capsella } \\
\text { bursa-pastoris with some species of the } \\
\text { Hordeion leporini alliance } \\
\text { Stellarietea mediae community dominated } \\
\text { by Capsella bursa-pastoris }\end{array}$ \\
\hline VIII & $\begin{array}{l}\text { Spergula } \\
\text { arvensis (1) } \\
\text { Stachys arvensis (1) } \\
\text { Coronilla dura (1) }\end{array}$ & Tuberaria guttata (1) & 6 & Poo bulbosae-Trifolietum subterranei \\
\hline IX & & $\begin{array}{l}\text { Andryala } \\
\text { integrifolia (1) }\end{array}$ & 10 & $\begin{array}{l}\text { Edge community rich in Helianthemetea } \\
\text { guttatae-Stellarietea mediae species and } \\
\text { with Poa bulbosa }\end{array}$ \\
\hline $\mathrm{X}$ & & & 11,12 & $\begin{array}{l}\text { Stellarietea mediae community and } \\
\text { Echium plantagineum community (Echio } \\
\text { plantaginei-Galactition tomentosae) }\end{array}$ \\
\hline $\mathrm{XI}$ & Aira caryophyllea (1) & & 4,5 & Poo bulbosae-Trifolietum subterranei \\
\hline XII & & $\begin{array}{l}\text { Anarrhinum } \\
\text { bellidifolium (1) }\end{array}$ & 9 & $\begin{array}{l}\text { Edge community rich in Helianthemetea } \\
\text { guttatae-Stellarietea mediae species and } \\
\text { with Poa bulbosa }\end{array}$ \\
\hline XIII & & Anagallis arvensis (1) & 7,8 & Poo bulbosae-Trifolietum subterranei \\
\hline
\end{tabular}

at least 10 years (AMS); Set C - Lightly grazed Mediterranean short swards in the last 10 years (LGMS); Set D - Trampled and ruderalised Mediterranean short swards in the last 10 years (TRMS); Set E - Feeding and/or resting livestock areas of Mediterranean short swards for at least 10 years (FRLAMS) (Table 2).

Groups 4, 5, 6, 7 and 8 are related with the Poo bulbosae-Trifolietum subterranei silicicolous phytosociological association (Table 3). This association configures the European priority habitat $6220 *$ (Pseudo-steppe with grasses and annuals of the Thero-Brachypodietea). Trifolium subterraneum-dominated Groups 4 and 7 are much less frequent than Poa bulbosa-dominated Groups 5, 6 and 8. The floristic composition of groups 6,7 and 8 are a result of extensive grazing mainly by sheep and to a lesser degree by goats and/or cattle, while Groups 4 and 5 correspond to Poa bulbosa swards rarely grazed by livestock.

An alphabetical list of abbreviated taxa used in the current text and in the phytosociological table is shown in Appendix I. 
Table 2

Relationship between Twinspan sets and land-use variables. Livestock load: 1- Very light; 2- Light; 3 - High;

4 - Very high. Regularity of grazing or livestock permanence: 1 - Very irregular use during 6 months;

2 - Irregular use during 6 months; 3 - Regular use during 6 months and 4 - Regular use all year round.

\begin{tabular}{llll}
\hline $\begin{array}{l}\text { Twinspan set/ } \\
\text { Land-use history } \\
\text { the last }\end{array}$ & Group & $\begin{array}{l}\text { Livestock } \\
\text { load }\end{array}$ & $\begin{array}{l}\text { Regularity } \\
\text { of grazing of } \\
\text { or livestock } \\
\text { permanence }\end{array}$ \\
\hline A (PLAMS) & 1 & 4 & 2 \\
& 2 & 4 & 2 \\
B (AMS) & 3 & 4 & 2 \\
C (LGMS) & 4 & 1 & 1 \\
& 5 & 1 & 1 \\
D (TRMS) & 7 & 2 & 3 \\
& 8 & 2 & 3 \\
E (FRLAMS) & 9 & 1 & 3 \\
& 10 & 2 & 2 \\
& 11 & 3 & 4 \\
& 13 & 3 & 4 \\
& 14 & 3 & 4 \\
\hline
\end{tabular}

Monte Carlo Permutation Test results for the Twinspan Sets (Table 4) show a highly significant difference $(p<0.01)$ between the penned areas (Set A) and both the Mediterranean short sward communities (Sets B and C) and the edge communities (Set D). The feeding and/or resting areas (SetE) also present a highly significant difference when compared with both Sets B and C. A highly significant difference is also observed between Sets C and D.

A significant difference $(\mathrm{p}<0.05)$ was obtained between Sets A and E and between Sets D and E.

\section{RELATIONSHIP BETWEEN SPECIES COMPOSITION DATA AND ECOLOGICAL VARIABLES}

The floristic and ecological patterns of the data were identified through the CCA and DCCA analyses.

Following the Monte Carlo Permutation Test carried out in a previous CCA $(\mathrm{p}<0.05)$ only environmental and land-use variables such as livestock load, regularity of grazing or livestock permanence and stoniness were selected as the key variables that best are related to the ordination model.

The DCCA ordination diagram (Figure 3) shows the relationship between the sets obtained previously by the TWINSPAN classification with the selected environmental and land-use variables. The first two axes of the DCCA explain $14.4 \%$ of species variation that are explained in $67.3 \%$ of the ecological variables selected. The first canonical axis eigenvalue is 0.441 with $\mathrm{p}=0.001$.

The relationship between species composition data and ecological variables shows:

- Axis 1 portrays the degree of naturalness of the five sets defined through the Twinspan classification by separating the feeding and/or resting livestock areas from the other sampled plots, thus reinforcing the first's older land-use history and higher intensity of use. The abandoned swards of the International Tagus region classified as Twinspan's Set B, has been placed farthest away from the samples with the highest intensity of use and highest animal load on the positive end of the axis.

- Axis 2 reveals a stoniness (soil depth) gradient that separates penned livestock areas from the rest as places with deeper soil depth were chosen to facilitate fence installation.

-Set B of Twinspan has a higher percentage cover of bryophytes and is strongly correlated to the presence of rock outcrops which indicates lack of intervention for several years and low agricultural aptitude respectively.

\section{DISCUSSION}

The main gradient resulting from the combination of livestock load, regularity of grazing or livestock permanence and land-use history of the last 10 years is responsible for the order of the 14 groups defined in the Twinspan dendrogram.

The floristic changes discovered in the Poo bulbosae-Trifolietum subterranei silicicolous phytosociological association resulted in the description of different subassociations by RIVAS GODAY \& LADERO (1970) and LADERO \& al. (1994). None of these subassociations is well represented in the study sites. 
Table 3

Poo bulbosae-Trifolietum subterranei Rivas Goday 1964

(Poetea bulbosae,Poetalia bulbosae, Trifolio subterranei-Periballion)

\begin{tabular}{llllllllllllllll}
\hline Altitude (m.a.s.1.) & 308 & 135 & 267 & 267 & 308 & 215 & 266 & 270 & 236 & 303 & 236 & 296 & 236 & 236 & 308 \\
N. species & 21 & 17 & 19 & 22 & 21 & 15 & 10 & 14 & 18 & 32 & 37 & 35 & 30 & 39 & 34 \\
Relevé N. & 1 & 2 & 3 & 4 & 5 & 6 & 7 & 8 & 9 & 10 & 11 & 12 & 13 & 14 & 15 \\
\hline
\end{tabular}

Characteristics

Poa bulbosa

Erodium botrys

Trifolium subterraneum

Astragalus pelecinus

Romulea bulbocodium

Trifolium glomeratum

Gynandriris sisyrinchium

Trifolium bocconei

Paronychia argentea

Other species

Leontodon longirostris

Herniaria scabrida

Plantago coronopus

Evax pygmaea

Logfia gallica

Ornithopus compressus

Tuberaria guttata

Chamaemelum fuscatum

Trifolium campestre

Aira caryophyllea

Cerastium glomeratum

Hymenocarpus lotoides

Aphanes microcarpa

Parentucellia latifolia

Spergula arvensis

Spergularia purpurea

Stachys arvensis

Trifolium cherleri

Hypochaeris glabra

Sanguisorba verrucosa

Vulpia bromoides

Anagallis arvensis

Capsella bursa-pastoris

Carlina racemosa

Coronilla dura

Filago lutescens

Hedypnois cretica

Juncus bufonius

Ornithopus pinnatus

Plantago bellardii

Teesdalia nudicaulis

Tolpis barbata

Veronica hederifolia

Chamaemelum mixtum

Euphorbia exigua

Gaudinia fragilis

Lamarckia aurea

Lathyrus angulatus

$$
\begin{aligned}
& \begin{array}{lllllllllllllll}
5 & 4 & 5 & 5 & 1 & 4 & 4 & 4 & 3 & 5 & 2 & 4 & 4 & 5 & 5
\end{array} \\
& +\quad 22+.1+. \quad 1.1+1 . \\
& \begin{array}{lllllllllllll}
. & 2 & 2 & 4 & \cdot & 1 & \cdot & \cdot & 2 & 5 & 2 & 2 \\
. & . & 1 & + & 2 & . & . & . & . & . & 2 & + & 2
\end{array} \\
& \text {. . . . }+4+\text {. } 1 \text {. . } 12
\end{aligned}
$$

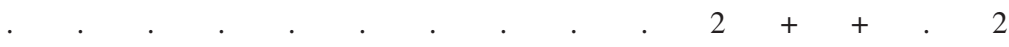

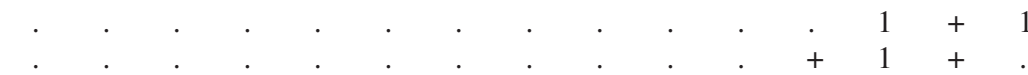

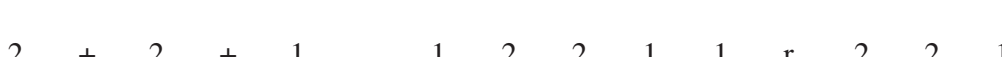

$$
\begin{aligned}
& \begin{array}{lllllllllllllll}
2 & + & 2 & + & 1 & . & 1 & 2 & 2 & 1 & 1 & \mathrm{r} & 2 & 2 & 1 \\
+ & . & + & 2 & + & . & . & 2 & + & 1 & + & 1 & 1 & 2 & 2
\end{array} \\
& 1 \mathrm{r}+\mathrm{r} . \quad . \quad 1.2 .21+ \\
& + \text {. } 1++ \text {. }+1+\text {. }+1
\end{aligned}
$$

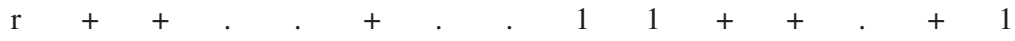

$$
\begin{aligned}
& \begin{array}{lllllllllllllll}
2 & . & 1 & . & 1 & + & . & 1 & . & 1 & + & . & + & + & \\
. & 2 & + & . & . & 1 & . & . & . & + & + & 1 & 2 & + & 2
\end{array}
\end{aligned}
$$

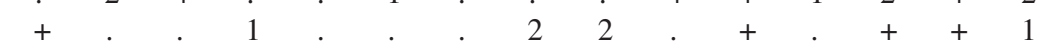

$$
\begin{aligned}
& \text {. . . . }+\quad+\quad 2+2+1
\end{aligned}
$$

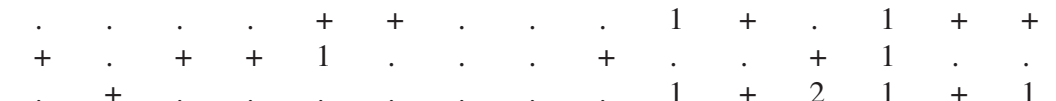

$$
\begin{aligned}
& +\quad 2 \quad 2 \quad 2 \\
& +\quad+2
\end{aligned}
$$




\begin{tabular}{|c|c|c|c|c|c|c|c|c|c|c|c|c|c|c|c|}
\hline Relevé N. & 1 & 2 & 3 & 4 & 5 & 6 & 7 & 8 & 9 & 10 & 11 & 12 & 13 & 14 & 15 \\
\hline Muscari comosum & . & . & + & + & . & . & . & . & . & . & . & + & . & . & . \\
\hline Plantago afra & . & . & . & . & 1 & + & 1 & . & . & . & . & . & . & . & . \\
\hline Plantago lagopus & . & . & . & 1 & . & . & . & . & . & . & + & . & . & 1 & . \\
\hline Роа аппиа & . & . & . & 1 & . & . & . & . & . & . & + & . & . & + & . \\
\hline Silene gallica & . & . & . & . & . & . & . & . & . & 1 & . & . & . & + & 1 \\
\hline Trifolium tomentosum & . & . & . & . & . & . & . & . & . & 2 & . & . & . & + & 2 \\
\hline Vulpia ciliata & . & + & . & . & . & + & . & . & . & . & . & + & . & . & . \\
\hline Avena barbata & . & + & . & . & + & . & . & . & . & . & . & . & . & . & . \\
\hline Bromus hordeaceus & . & . & . & . & . & . & . & . & . & + & + & . & . & . & . \\
\hline Calendula arvensis & + & . & . & . & 1 & . & . & . & . & . & . & . & . & . & . \\
\hline Chaetonychia cymosa & . & . & . & . & . & . & . & . & . & . & + & . & . & . & + \\
\hline Dipcadi serotinum & . & . & . & . & . & . & . & . & . & . & . & + & . & . & + \\
\hline Echium plantagineum & . & . & . & . & . & . & . & . & . & + & 1 & . & . & . & . \\
\hline Lotus hispidus & . & . & . & . & . & . & . & + & + & . & . & . & . & . & . \\
\hline Raphanus raphanistrum & + & . & . & . & . & . & . & . & . & . & + & . & . & . & . \\
\hline Senecio minutus & + & . & . & . & . & . & . & . & . & + & . & . & . & . & . \\
\hline Stellaria media & $\mathrm{r}$ & . & . & . & . & . & 1 & . & . & . & . & . & . & . & . \\
\hline Trifolium arvense & . & . & . & . & . & . & . & . & . & . & . & + & . & . & + \\
\hline Trifolium stellatum & . & . & . & . & . & . & . & . & . & 2 & . & . & + & . & . \\
\hline Tuberaria lignosa & . & . & . & . & + & . & . & . & 1 & . & . & . & . & . & . \\
\hline
\end{tabular}

Other species: Linaria spartea and Vulpia myurus + in 2; Stellaria graminea 2 in 4; Anarrhinum bellidifolium, Diplotaxis catholica, Geranium molle, Omphalodes linifolia and Urginea maritima + in 5; Aegilops triuncialis, Sherardia arvensis and Vulpia geniculata + in 6; Linaria incarnata + in 9; Dactylis hispanica and Plantago lanceolata + in 10; Juncus capitatus and Rumex gallicus +, Eryngium campestre 1 and Parentucellia viscosa 2 in 11; Rumex angiocarpus + , Linaria amethystea 1, Trifolium alexandrinum and Agrostis pourretii 2 in 12; Briza maxima and $B$. minor + in 13; Crepis haenseleri, Ranunculus muricatus and Trifolium angustifolium + in 14; Illecebrum verticillatum and Polycarpon tetraphyllum +, Sesamoides purpurascens 1 and Stipa capensis 3 in 15.

Localities:1, 9 15: Near Soalheira (Rosmaninhal); 2: Near Vila-Velha-de-Rodão (Castelo Branco); 3-5, 7, 8, 10: Near Soalheira - Rosmaninhal; 6: Near Idanha-a-Nova; 11, 13, 14: Near Segura; 12: Near Rosmaninhal.

\section{Table 4}

Monte Carlo Permutation Test results for the Twinspan Sets $(* * p<0.01 ; * p<0.05)$

\begin{tabular}{lllll}
\hline $\begin{array}{l}\text { Twinspan } \\
\text { Groups }\end{array}$ & $\mathrm{B}$ & $\mathrm{C}$ & $\mathrm{D}$ & $\mathrm{E}$ \\
\hline $\mathrm{A}$ & $0.0001^{* *}$ & $0.0001^{* *}$ & $0.0001^{* *}$ & $0.0150^{*}$ \\
$\mathrm{~B}$ & & 0.1204 & 0.1332 & $0.0001^{* *}$ \\
$\mathrm{C}$ & & & $0.0001^{* *}$ & $0.0001^{* *}$ \\
$\mathrm{D}$ & & & & $0.0179^{*}$ \\
$\mathrm{E}$ & & & & \\
\hline
\end{tabular}

Poa bulbosa is more abundant in lightly grazed Mediterranean short swards (Set $\mathrm{C}$ with an average cover of $71.25 \%$ ) than in abandoned Mediterranean short swards (Set B with an average cover of $60.00 \%$ ) and edge communities rich in Helianthemetea guttatae or Stellarietea mediae species and with Poa bulbosa (Set D with an average cover of $30 \%$ ). This species has disappeared from feeding and/or resting areas (Set E) and is residual in holding pens (Set A) where it occurs in one of the three sampled plots with an abundance of $2 \%$. According to RIVAS GODAY (1964) overgrazing of Poa bulbosa communities increases the nitrate levels, resulting in the reduction of palliative species and their replacement by nitrophilous species of low forage interest, thus lowering the feeding value for livestock. The ability of herbivores to select better quality components of the swards has also been documented in other studies (HEADY, 1964; HEJCMAN \& al., 2008). If nitrification is too great these swards change to Chenopodietalia muralis communities (AMOR \& al., 1993). The same was found in this study. The communities of Stellarietea mediae, Echium plantagineum and Hordeum leporinum identified at the feeding and/or resting areas and penned livestock areas suggest that the higher nitrate levels are the main reason 


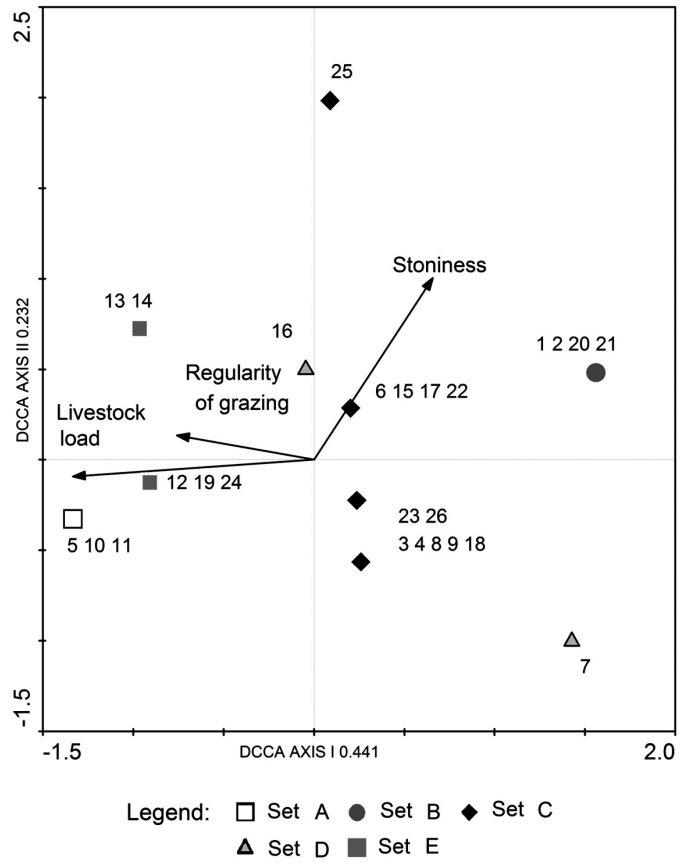

Figure 3. - Detrended Canonical Correspondence Analysis (DCCA). Biplot with samples and ecologicalvariables. A, B, C, D and E: sets resulting from the TWINSPAN classification.

for the disappearance or residual presence of $\mathrm{Poa}$ bulbosa.

Poa bulbosa is the only Poetea bulbosae species present in Set $\mathrm{D}$. The similarity between this group and Set $\mathrm{B}(\mathrm{p}=0.1332)$ is probably due to the smaller difference in average percentage cover of Poa bulbosa - $30.00 \%$ - as opposed to the greater difference $-41.25 \%$ - observed between Sets $C$ and $D(p=0.0001)$. This also holds true for Sets B and C ( $p=0.1204)$ with an $11.25 \%$ difference. A highly significant difference occurs exclusively between extensively grazed and trampled and ruderalised plots which seem to result from a differential use by livestock.

There is a marked difference between Trifolium subterraneum-dominated are as and Poa bulbosa-dominated areas:

- Trifolium subterraneum-dominated areas may be expanded through extensive grazing as clover seeds are buried through sheep trampling (RIVAS GODAY, 1964). The annual legumes that constitute these patches disappear in autumn/winter, which they pass in the form of seed, indicative of a phenological variation in the floristic composition of these communities also identified by RUIZ \& PÉREZ (2009).

- extensive grazing favours the abundance of Poa bulbosa in Poa bulbosa-dominated areas by promoting reproduction while the consequent nutrient input helps to sustain a higher plant density and higher biomass production.

Extensive live stock grazing can thus improve these short swards not only in surface area but also in productivity and biomass density.

The absence of livestock grazing results in a territorial reduction of Trifolium subterraneumand Poa bulbosa-dominated areas and in a density/cover reduction of Poa bulbosa-dominated areas. The abandonment of grazing seems to change these pastures to a state where Poa bulbosa is less abundant and Trifolium subterraneum occupies smaller patches (Set B in the study area).

Environmental and land-use variables such as livestock load, regularity of grazing or livestock permanence and stoniness were the selected by the CCA (with Monte Carlo Permutation test) as the key variables related to the floristic patterns observed in the ordination revealing that grazing variables have influence in the floristic composition of perennial swards of Poa bulbosa.

The DCCA results revealed that only a small fraction of the species variation is related to ecological factors. A moderate amount of unexplained variance was obtained, which is a common finding in ordination models (ØKLAND, 1999).

Deep and regular soil tillage and land abandonment to natural succession are decisive factors in the disappearance of these Mediterranean short swards. The control of woody vegetation through grazing or cutting is a fundamental conservation measure in line with SAN Miguel (2008) and ICNB (2006).

Their maintenance relies on controlling woody vegetation in order to hamper the process of ecological succession. Cutting woody vegetation is preferable to soil tillage as this second management technique diminishes the abundance of $\mathrm{Poa}$ bulbosa that may need one to several years to attain the initial state.

In some circumstances these communities are highly enriched in Helianthemetea guttatae com- 
panion species, namely in situations of great oligotrophy and/or very shallow soils where Poa bulbosa has not reached its maximum dominance or does not have conditions to develop. It is thus very frequent to observe mosaics of Poa bulbosa communities with Helianthemetea guttatae communities.

Mediterranean perennial swards of Poa bulbosa are a very important food source for wild rabbit populations. This species composes the diet of over forty species found in its natural range (Portugal, Spain and northwestern Africa (Morocco and Algeria); IUCN, 2011a), including several of the birds of prey nesting in the International Tagus region. The Imperial eagle (Aquila adalberti) consumes $40-80 \%$ of its diet in rabbits (IUCN, 2011b) and the decline of Oryctolagus cuniculus (Conservation Status in Portugal: Near
Threatened; (CABRAL \& al., 2005) has been linked to the near extinction of this specialist predator (ZoFio \& VEGA, 2000). Therefore, in Spain, much effort is being made to increase the area of Poetalia communities in the habitat of endangered species (SAN MiguEL, 2008) dependent on the European rabbit.

\section{ACKNOWLEDGEMENTS}

This study was supported by the Foundation for Science and Technology (FCT) through the $\mathrm{PhD}$ project SFRH/BD/ 29515/2006. The authors wish to thank Rui Ribeiro and the International Tagus Natural Park for all the help provided while carrying out field work in 2009 and 2010 and Carla Cruz for the revision of the manuscript and for all her valuable comment sand David Tucker for proof-reading the English version.

\section{SYNTAXONOMICAL SCHEME}

Syntaxa were named according to the International code of Phytosociological Nomenclature (ICPN), 3rd edition (WEBER \& al., 2000).

ISOETO-NANOJUnCETEA Br.-Bl. \& Tüxen ex Westhoff, Dijk \& Passchier 1946

Isoetetalia Br.-Bl. 1936

Agrostion salmanticae Rivas Goday 1958

(=Agrostion pourretii Rivas Goday 1958 nom. mut.)

Pulicario uliginosae-Agrostietum salmanticae Rivas Goday 1956

(=Pulicario paludosae-Agrostietum pourretii Rivas Goday 1956 nom. mut.)

STELLARIETEA MEDIAE Tüxen, Lohmeyer \& Preising ex von Rochow 1951

Chenopodio-Stellarienea Rivas Goday 1956

Thero-Brometalia (Rivas Goday \& Rivas-Martínez ex Esteve 1973) O. Bolòs 1975

[Brometalia rubenti-tectorum Rivas-Martínez \& Izco 1977]

Echio plantaginei-Galactition tomentosae O. Bolòs \& Molinier 1969

Echium plantagineum community

Sisymbrietalia officinalis J. Tüxen in Lohmeyer \& al. 1962 em. Rivas-Martínez, Báscones, T.E.

Díaz, Fernández-González \& Loidi 1991

Hordeion leporini Br.-Bl. in Br.-Bl., Gajewski, Wraber \& Walas 1936 corr. O. Bolòs 1962

Hordeum leporinum community

POETEA BULBOSAE Rivas Goday \& Rivas-Martínez in Rivas-Martínez 1978

Poetalia bulbosae Rivas Goday \& Rivas-Martínez in Rivas Goday \& Ladero 1970

Trifolio subterranei-Periballion Rivas Goday 1964]

[Periballio-Trifolion subterranei Rivas Goday 1964 nom. invers.]

Trifolio subterranei-Periballenion

Poo bulbosae-Trifolietum subterranei Rivas Goday 1964

[Trifolio subterranei-Poetum bulbosae Rivas Goday 1964 nom. invers.] 


\section{APPENDIX I: FLORISTIC APPENDIX}

An alphabetical list of abbreviated taxa present in the article and in the phytosociological table is shown below.

Coronilla dura: Coronilla repanda (Poir.) Guss. subsp. dura (Cav.) Cout.

Crepis haenseleri: Crepis vesicaria L. subsp. haenseleri (DC.) P.D. Sell

Dactylis hispanica: Dactylis glomerata L. subsp. hispanica (Roth.) Nyman

Hordeum leporinum: Hordeum murinum L. subsp. leporinum (Link) Arcang.

Leontodon longirostris: Leontodon taraxacoides (Vill.) Mérat subsp. longirostris Finch \& P.D. Sell

Rumex angiocarpus: Rumex acetosella L. subsp. angiocarpus (Murb.) Murb.

Rumex gallicus: Rumex bucephalophorus L. subsp. gallicus (Steinh.) Rech. fil

\section{REFERENCES}

Aguiar, C. - 2000 - Flora e Vegetação da Serra de Nogueira e do Parque Natural de Montesinho - PhD diss. Sup. Inst. Agron. Tec. Univ. Lisbon. Lisbon.

Amor, A., Ladero, M. \& Valle, C. - 1993 - Flora y vegetación vascular da la comarca de la Vera y laderas meridionales de la sierra de Tormantos (Cáceres, España) Studia Bot. 11: 11-207.

Borcard, D., Legendre, P. \& Drapeau, P. - 1992 - Partialling out the spatial component of ecological variation -Ecology 73:1045-1055.

Braun-Blanquet, J. -1964- Pflanzensoziologie. 3rd ed. Grundzüge der Vegetationskunde - Springer-Verlag, Vienna, New York.

Cabral, M. (coord.), Almeida, J., Almeida, P., Dellinger, T., Ferrand de Almeida, N., Oliveira, M., Palmeirim, J., Queiroz, A., Rogado, L. \& Santos-Reis, M. (Eds.) 2005 - Livro Vermelho dos Vertebrados de Portugal Inst. Cons. Nat. Lisboa. 660 pp.

Cano, E., Ladero, M., García-Fuentes, A., Pinto-Gomes, C. \& Cano-Ortiz, A. - 2007- Current state of the Poetea bulbosae class in the Iberian Peninsula - Phytocoenologia 37(3-4): 645-661.

Cantó, P. - 2004- Estudio fitosociológico y biogeográfico de la sierra de San Vicente y tramo inferior del valle del Alberche (Toledo, España) - Lazaroa 25: 187-249.

Carvalhinho, J. - 2004 - A flora e a vegetação dos habitats naturais do Parque Natural do Tejo Internacional: Vegetação, Vol. II - Instituto da Conservação da Natureza, Parque Natural do Tejo Internacional. 464 pp.

Castroviejo, S. \& al. -1986-2010 - Flora iberica C.S.I.C., Madrid.

Chambino, M. - 2000 - Rosmaninhal - Lembranças de um mundo cheio - Açafa n. ${ }^{\circ}$ 3. Assoc. Est. Alto Tejo, Vila Velha de Ródão.

Chytrý, M. \& Otýpková, Z. - 2003 - Plot sizes used for phytosociological sampling of European vegetation J. Veg. Sci. 14: 563-570.
Council Directive 92/43/EEC of 21 May 1992 on the conservation of natural habitats and of wild fauna and flora (The 'Habitats Directive') - Off. J. Eur. Union L206, 22.07.1992.

de la Fuente, V. - 1985 - Vegetación orófila del occidente de la provincia de Guadalajara (España) - Lazaroa 8: 123-219.

Delibes, M., Rodrigues, A. \& Ferreras, P. -2000- Action Plan for the Conservation of the Iberian Lynx (Lynx pardinus) in Europe - Convention on the conservation of European wildlife and natural habitats. Pp. 1-40. Oslo, Norway.

Dengler, J., Löbel, S. \& Dolnik, C. -2009- Species constancy depends on plot size - a problem for vegetation classification and how it can be solved. - J. Veg. Sci. 20: $754-766$

Directive 2009/147/EC of the European Parliament and of the Council of 30 November 2009 on the conservation of wild birds (The 'Birds Directive') - Off. J. Eur. Union L 20, 26.1.2010.

EC (European Commission) - 2007- The Interpretation Manual of European Union Habitats, EUR27 - Eur. Com. DG Env., Brussels. http://ec.europa.eu/environment/nature/legislation/habitatsdirective/docs/2007_07_ im.pdf. [January, 2012].

Franco J. - 1971, 1984- Nova Flora de Portugal (Continente e Açores), vols. I-II - Sociedade Astória, Lda., Lisboa.

Franco, J. \& Rocha Afonso, M. -1994, 1998, 2003 - Nova Flora de Portugal (Continente e Açores), Vol. III - Escolar Editora, Lisboa.

Galán De Mera, R., Alonso, J. \& Orellana, V. -2000 - Pasture communities linked to ovine stock. A synthesis of the Poetea bulbosae class in the western Mediterranean Region - Phytocoenologia 30: 223-267.

Géhu, J. \& Rivas-Martínez, S. -1981 - Notions Fondamentales de Phytosociologie in Syntaxonomie - J. Cramer, Vaduz. 
González, L. \&San Miguel, A. (coord.) -2004- Manual de buenas prácticas de gestión en fincas de monte mediterráneo de la red Natura 2000. - M M Medio Amb., Madrid. Spain.

Heady, H. - 1964 - Palatibility of herbage and animal preference - J. Range Manag. 17: 76-82.

Heikkinen, R., Luoto, M., Virkkala, R. \& Rainio, K. 2004- Effects of habitat cover, landscape structure and spatial variables on the abundance of birds in an agricultural-forest mosaic - J. Appl. Ecol.41: 824-835.

Hejcman, M., Žáková I., Bílek, M., Bendová, P., Hejcmanová, P., Pavlů, V. \& Stráska, M. - 2008 - Sward structure and diet selection after sheep introduction on abandoned grassland in the Giant Mts, Czech Republic - Biologia 63(4): 506-514.

Hill, M. \& Šmilauer, P. - 2005- TWINSPAN for Windows version 2.3. - Centre for Ecology and Hydrology \& University of South Bohemia, Huntingdon \& Ceske Budejovice.

ICNB -2006- Plano Sectorial da Rede Natura 2000. Caracterização de Valores Naturais - Available at: http://portal.icnb.pt/NR/rdonlyres/BCECDC1D-61084EF8-838D-09C64DA89DFB/0/6220.pdf [December, 2011].

ICNB -2007- Plano de Ordenamento do Parque Natural do Tejo Internacional. Discussão Pública. Estudos de Caracterização - Parque Natural do Tejo Internacional, Castelo Branco.

IUCN Red List of Threatened Species - 2011a - Oryctolagus cuniculus - http://www.iucnredlist.org/apps/redlist/details/41291/0 [January 26, 2012].

IUCN Red List of Threatened Species - 2011b - Aquila adalberti- http://www.iucnredlist.org/apps/redlist/details/106003534/0 [January 26, 2012].

Izco, J., Amigo Vázquez, J. \& Léon, D.G. -2000- Análisis y classificación de la vegetación de Galicia (España), II. La vegetación herbácea - Lazaroa 21: 25-50.

Jongman, R., ter Braak, C. \& van Tongeren, O. (eds.) 1995 - Data Analysis in Community and Landscape Ecology - Cambridge University Press, Cambridge, UK, 324 pp.

Ladero, M., Amigo, J. \& Romero, M. - 1994- Nuevos nombres para dos subassociaciones de Poo bulbosae-Trifolietum subterranei Rivas Goday 1964 - Lazaroa 14: 171-172.

Loidi, J., Biurrun, I. \& Herrera, M. — 1997- La vegetación del centro-septentrional de España - Itinera Geobot. 9: 161-618.

Monteiro-Henriques, T. -2010 - Fitossociologia e paisagem da bacia hidrográfica do rio Paiva e das bacias contíguas da margem esquerda do rio Douro, desde o Paiva ao rio Tejo (Portugal) (PhD diss.) - Sup. Inst. Agron Tech. Univ. Lisbon, Lisbon.

Monteserrat, P. \& Fillat, F. - 1999- The systems of grasslands management in Spain - In: Breymeler A. L. \& Goodall D.W. (Eds.). Ecosystems of the World 17B: Managed Grasslands. Pp. 37-70. Elsevier, Amsterdam.
Mueller-Dombois, D. \& Ellenberg, H. -1974- Aims and methods of vegetation ecology - John Wiley \& Sons, New York. 547 pp.

Økland, R. - 1999- On the variation explained by the ordination and constrained ordination axes $-\mathrm{J}$. Veg. Sci. 10: 131-136.

Otýpková, Z. \& Chytrý, M. -2006- Effects of plot size on the ordination of vegetation samples - Appl. Veg. Sci. 17 (4): 465-472.

Pizarro, J. - 1995- Contribución al estudio taxonómico de Ranunculus L. subgen. Batrachium (DC) A. Gray (Ranunculaceae) - Lazaroa 15:21-113.

Podani, J. - 2006- Braun-Blanquet's legacy and data analysis in vegetation science - J. Veg. Sci. 17: 113117.

Ríos, S. \& Salvador, F. -2009- 6220 Pastizales xerofíticos mediterráneos de vivaces y anuales - In: VV. AA., Bases ecológicas preliminares para la conservación de los tipos de hábitat de interés comunitario en España. M $^{\circ}$ Medio Amb. Med. Rur. Mar., Madrid. 88 p.

Rivas Goday, S. \& Ladero, M. - 1970 - Pastizales cespitosos de Poa bulbosa L. Origen, sucesión y sistemática - An. R. Acad. Farmacia 36: 139-181.

Rivas Goday, S. \& Rivas-Martínez, S. - 1963- Estudio y Classificación de los Pastizales Españoles - Mo Agric. Madrid. 269 pp.

Rivas Goday, S. - 1964- Vegetación y Flórula de la Cuenca Extremeña del Guadiana (Vegetación y Flórula de la Provincia de Badajoz) - Excma. Diputacion Provincial de Badajoz, Madrid.

Rivas-Martínez, S. - 2005 - Avances en Geobotánica. Discurso de Apertura del Curso Académico de la Real Academia Nacional de Farmacia del año 2005.

Rivas-Martínez, S. -2007- Mapa de series, geoseries y geopermaseries de vegetación de España. [Memoria del mapa de vegetatión potencial de España] - Itinera Geobot. 17: 1-435.

Romero Buján, M. \& Amigo Vázquez, J. -1994- Los pastos de Poa bulbosa L. en Terra de Lemos (Lugo): revisión de la clase Poetea bulbosae Rivas Goday \& Rivas Martínez in Rivas Martínez 1978 en el noroccidente ibérico. - Lazaroa 14: 111-123.

San Miguel, A. (coord.) -2007- Manual para la gestión del lince Iberico (Lynx pardinus) y de su presa principal, el conejo de monte (Oryctolagus cuniculus) - Fundación CBD-Habitat. Madrid.

San Miguel, A. -2008 - Management of Natura 2000 habitats. *Pseudo-steppe with grasses and annuals (TheroBrachypodietea) 6220. Tech. Report - European Commission. Available at: http://ec.europa.eu/environment/nature/natura2000/management/habitats/pdf/6220 Pseudo_steppe.pdf[December, 2011].

Sánchez Rodríguez, M., Amor, A. \& Ladero, M. -2006Estudio fitosociológico y bromatológico de los pastizales con interés ganadero en la provincia de Salamanca Studia Bot. 25: 9-61. 
Santos, M., Ladero, M. \& Amor, A. -1988- Vegetación de las intercalaciones básicas de la provincia de Cáceres (Extremadura, España) - Studia Bot. 7: 9147.

Silva, V., Pinto-Cruz, C. \& Espírito-Santo, M.D. - 2009Temporary ponds and hygrophilous grasslands plant communities in Monfurado Site of Community Importance - Lazaroa 30: 81-88.

ter Braak, C. \& Smilauer, P. -2002- CANOCO reference manual and user's guide to Canoco for Windows: Software for Canonical Community Ordination (version 4.5) - Microcomputer Power, Ithaca, NY, US. $500 \mathrm{pp}$.

Tichý, L. - 2002- JUICE, software for vegetation classification - J. Veg. Sci.13: 451-453.

Villafuerte, R., Lazo, A. \& Moreno, S. - 1997- Influence of food abundance and quality on rabbit fluctuations: Conservation and management implications in Doñana
National Park - Rev. Ecol.(Terre et Vie) 52(4): $345-$ 356.

Virgos, E., Cabezas-Diaz, S. \& Lozano, J. -2005- El declive del conejo en Espana: evidencias a partir de las estadísticas de caza - Quercus 236: 16-20.

Ward, D. - 2005 - Reversing Rabbit Decline: One of the Biggest Challenges for nature conservation in Spain and Portugal. - IUCN Lagomorph Specialist Group. Switzerland. $54 \mathrm{pp}$.

Weber, H., Moravec, J. \& Theurillat, J. -2000 - International Code of Phytosociological Nomenclature. 3rd edn. - J.Veg.Sci. 11: 739-768.

Willott, S., Miller, A., Incoll, L. \& Compton, S. -2000The contribution of rabbits (Oryctolagus cuniculus L.) to soil fertility in semi-arid Spain - The Biology and Fertility of Soils 31: 379-384.

Zofio, J. \& Veja, I. -2000 - El Aguila Imperial - Gran Fauna 4.

Recibido: 28 febrero 2012

Aceptado: 10 septiembre de 2012 